\title{
Integrated Management of Wilt Complex Disease in Bell Pepper (Capsicum annuum L.)
}

\author{
Tariq R. Rather ${ }^{1}$, V. K. Razdan ${ }^{2}$, A. K. Tewari ${ }^{3}$, Efath Shanaz ${ }^{1}$, Z. A. Bhat ${ }^{1}$, Mir G. Hassan ${ }^{1} \&$ T. A. Wani ${ }^{1}$ \\ ${ }^{1}$ S-K. University of Agricultural Sciences \& Technology, Shalimar J\&K, India \\ ${ }^{2}$ Division of Plant Pathology, S K UAST - Jammu J\&K, India \\ ${ }^{3}$ GBPUAS\&T-Pantnagar Uttrakhand, India
}

Correspondence: Dr. Tariq Rasool Rather, AARC Pahnoo SKUAST-K Shalimar Srinagar J\&K, India. Tel: 91-959-610-0323. E-mail: tariqrasoolrather@gmail.com

Received: March 21, 2012 Accepted: April 5, 2012 Online Published: May 22, 2012

doi:10.5539/jas.v4n7p141 URL: http://dx.doi.org/10.5539/jas.v4n7p141

\begin{abstract}
Effect of various disease management tools on seedling emergence, wilt incidence and yield of bell pepper (Capsicum annuum L.) Var. California Wonder was studied as part of integrated management strategies under both glass house and field conditions. Different fungicides were tested against the four wilt pathogens viz, Fusarium oxysporum, Phytopthora capsici, Rhizoctonia solani and Sclerotium rolfsii under in-vitro conditions. The fungicides viz, Captan, Carbendazim, Metalaxyl and Carboxin which were found effective under in-vitro conditions were further tested individually as well as in combinations under glass house conditions. Seed treatment followed by seedling treatment with fungicides proved ineffective in controlling wilt incidence disease, however, besides seed treatment and seedling treatment when fungicides were sprayed at crown region of the plant, wilt incidence was significantly reduced. Seed treatment + seedling treatment + spraying of Carbendazim + Metalaxyl proved most effective and recorded $59.8 \%$ disease reduction over check under field conditions. Integration of Captan + Metalaxyl with Trichoderma harzianum and T. virens also proved superior compared to their individual treatments.
\end{abstract}

Keywords: integrated management, wilt complex, Capsicum annuum

Abbreviations: ST-Seed Treatment, SD-Seedling Dip, $\mathrm{Th}_{2}$-Trichoderma harzianum, $\mathrm{TV}_{2}-T$. viride, Gv $\mathrm{G}_{3}$ T. virens

\section{Introduction}

Bell pepper locally named as Shimla Mirch (Capsicum annuum L.) is infected by a number of diseases, among them wilt complex has gained major importance in the State of Jammu and Kashmir from the last 15-18 years and the losses caused by disease are up to the extent of 30-40 per cent (Anonymous, 1989). The wilt disease, incited by a number of pathogens, is the devastating soil-borne disease and hence difficult to manage. The disease has been observed to be caused by Fusarium spp., Phytophthora capsici and Rhizoctonia solani (Shali, 2000; Najar, 2001). Keeping in view the etiology, exorbitant losses and lack of information regarding integrated management of wilt complex disease using bio-control agents and chemicals, the present studies were conducted to evolve the effective management strategies involving most effective chemicals and bio-control agents.

\section{Research Methods}

The pathogens viz., Fusarium oxysporum, Rhizoctonia solani, Phytophthora capsici and Sclerotium rolfsii were isolated from bell pepper plants affected with wilt complex disease in different areas of Jammu region. The pure cultures of pathogens were maintained on PDA/carrot agar media at $4^{\circ} \mathrm{C}$. F. oxysporum, R. Solani and $S$. rolfsii were mass multiplied on pre-boiled autoclaved sorghum grains, whereas, $P$. capsici was mass multiplied on sand carrot broth medium.

\subsection{In-vitro Evaluation of Fungicides against Wilt Complex Pathogens}

The efficacy of fungicides viz. captan, copper oxychloride, mancozeb, mancozeb + carbendazim (Saaf), mancozeb + metalaxyl (Ridomil MZ), carbendazim, metalaxyl, carboxin, thiophanate methyl were tested against each pathogen under in-vitro condition by poisoned food technique (Schmitz, 1930) to find out the effective fungicides. The Petri-plates containing PDA/carrot agar media (for P. capsici) amended with desired concentration of 
fungicides were inoculated with $5 \mathrm{~mm}$ discs of pathogen and incubated with $25+1{ }^{\circ} \mathrm{C}$ temperature. The plates without any fungicides served as check. The radial mycelial growth was recorded in each treatment and percent inhibition over check was calculated.

\subsection{In-vivo Evaluation of Fungicides against Bell Pepper Wilt Complex Pathogens}

The fungicides found effective in-vitro were tested in-vivo as seed + seedling treatment alone and in combinations with spraying at crown region of the plant. The studies were carried out in earthen pots containing sterilized soil and FYM (2:1). The seeds of bell pepper cv. California wonder treated with fungicides viz., carbendazim, carboxin, metalaxyl (@0.2\%), captan, carboxin + metalaxyl (1:1), carbendazim+ metalaxyl (1:1) (@0.3\%), captan + metalaxyl (1.5:1) and carbendazim + captan (1:1.5) (@ 0.35\%) were sown in pathogen inoculated pots. The 45 day old seedlings were uprooted from the pots and subjected to the seedling dip in different fungicides (same as in seed treatment) for 30 minutes and were planted again in pathogen inoculated pots. The spraying of the fungicides at crown region of the plant was done at 15 days interval after the initiation of wilt disease. The fungicides viz., carboxin, carbendazim and metalaxyl were applied @ $0.1 \%$, whereas captan was applied @ $0.2 \%$ concentration.

\subsection{Compatibility of Bio-agents with Fungicides}

The fungicides found effective under in-vitro conditions viz., carbendazim, carboxin, metalaxyl were tested at concentrations i.e. 50,100,250 ppm and captan at 100, 250, $500 \mathrm{ppm}$ against Trichoderma harzianum $\left(\mathrm{Th}_{2}\right), T$. viride $\left(\mathrm{Tv}_{2}\right)$ and $T$. virens $\left(\mathrm{Gv}_{3}\right)$ respectively, to examine their inhibitory effect on the mycelial growth of the antagonists using poisoned food technique $\left(\mathrm{Schmitz}, 1930^{3}\right)$. Theses antagonist isolates were found most effective against wilt pathogens under both in-vitro and in-vivo conditions in other experiments. The PDA plates containing desired concentration of fungicides were inoculated at the centre with the mycelial discs $(5 \mathrm{~mm})$ of actively growing culture of bio-agents. The plates inoculated with bio-agents but without fungicides served as check. The plates were incubated at $26+1^{\circ} \mathrm{C}$ for 10 days. The observation on radial growth of the antagonists were recorded in each treatment and per cent inhibition over check was calculated.

\subsection{Integration of Chemicals and Bio-agents against Wilt Complex Disease}

\subsubsection{Glass House Studies}

The effective/compatible fungicides (captan + metalaxyl, carbendazim + metalaxyl and carboxin + metalaxyl) and bio-agents (Trichoderma viride and T. virens) under in-vitro and glass house conditions were evaluated in integration to observe their effects on wilt complex disease. The seeds were first treated with reduced doses $(1 \mathrm{~g} / \mathrm{kg}$ seed) of fungicides followed by antagonists. The treated and untreated seeds were sown in pots containing sterilized soil. Forty-five day old seedlings were uprooted and soaked in respective fungicidal and antagonist suspensions. The seedlings were transplanted in pots inoculated with all the test pathogens. The fungicides were sprayed at crown region at 15 days intervals after the initiation of wilt disease. Observations on wilt incidence were recorded at regular intervals up to the maturity of the crop.

\subsubsection{Field Studies}

To study the effect of seed + seedling treatment of fungicides and bio-agents alone and in combination followed by spraying at crown region of the plant against wilt complex disease, a field experiment was laid out in a randomized block design with three replications at Basht village of Chenani area of Jammu region. Seeds of bell pepper cv. California wonder were treated with fungicide and bio-agents as in pot house studies. Seeds were sown in first week of March and forty-five day old seedlings were uprooted and subjected with each of the treatment (as under glass house conditions) and transplanted during mid-April. Four sprays of fungicides at 15 days interval, starting with the initiation of wilt disease were given at crown region of plant. The antagonists $(20 \mathrm{~g}$ each) were properly mixed with $2 \mathrm{~kg}$ FYM and then mixed with the top soil layer of plots $(2 \times 2 \mathrm{~m})$. The observations on wilt incidence and yield were recorded in each treatment.

\section{Analysis Results}

\subsection{In-vitro Evaluation of Fungicides against Wilt Complex Pathogens}

The data presented in Table 1 indicates that carbendazim and captan completely inhibited the growth of $F$. oxysporum at 50 and $500 \mathrm{ppm}$ concentrations, respectively. The growth of $P$. capsici was completely inhibited by metalaxyl at $50 \mathrm{ppm}$ concentration, captan and metalaxyl+ mancozeb at $500 \mathrm{ppm}$ concentration. Carboxin (50ppm) proved superior over other fungicides in inhibiting the growth of $R$. solani. The complete inhibition of mycelial growth of $R$. solani was also observed in carbendazim and thiophanate methyl at $250 \mathrm{ppm}$ concentrations. None of the chemicals tested could completely inhibit the growth of $S$. rolfsii, although, captan was most effective, 
followed by metalaxyl+mancozeb and mancozeb+carbendazim at $500 \mathrm{ppm}$ concentration each. Similar observations have been recorded by Sharma et al. (2002) with respect to carbendazim, copper oxychloride, captan and Ridomol MZ against $F$. oxysporum. Babadoost and Islam (2003) found metalaxyl as highly inhibitory to the mycelial growth of $P$. capsici under in-vitro conditions. Similar results of carbendazim, captan, thiophanate methyl and carboxin against R. solani (Dubey \& Patel, 2001) and captan against S. rolfsii (Chowdhary et al., 1998) have also been recorded.

\subsection{In-vivo Evaluation of Fungicides against Wilt Complex Pathogens}

Seed treatment with different fungicides and their suitable combinations revealed that all the fungicides and their combinations resulted in significantly superior emergence of bell pepper seedlings as compared to check (Table 2). The highest seedling emergence $(79.5 \%)$ with $47.7 \%$ increase over check was observed with carbendazim + metalaxyl followed by captan +carbendazim $(78.5 \%)$ and captan +metalaxyl $(78.0 \%)$. The increase in seedling emergence by carbendazim, captan, metalaxyl and other fungicides in different crops have been reported by different workers (Babadoost and Islam, 2002). Besides fungicidal action against pathogens the beneficial side effects of carbendazim and metalaxyl like seed germination, promotion of seedling growth etc. are well known.

The data in Table 2 indicate that seed +seedling treatment with fungicides protect the plants up to 40days after transplanting (DAT) and significantly lesser wilt incidence was observed than control. Seed +seedling treatment followed by spray of carbendazim + metalaxyl and captan +metalaxyl resulted in significantly lesser wilt incidence of 25.0 and $33.3 \%$, respectively, after 100 DAT, compared to $100 \%$ incidence in check at 40 DAT. The fungicidal combination of captan +carbendazim and carboxin + metalaxyl also recorded significantly lower wilt incidence (45.8 and $58.3 \%$, respectively) as compared to check and fungicides applied only as seed +seedling dip treatment. The results were in agreement with findings of Simon et al. (1990), who reported that spraying metalaxyl at the lower stem of Capsicum annum plants gave effective control of wilt incidence caused by Phytophthora capsici.

\subsection{Compatibility of Bio-agents with Fungicides}

The results (Table 3) showed that mycelial growth of Trichoderma viride $\left(\mathrm{Tv}_{2}\right)$ and T. virens $\left(\mathrm{Gv}_{3}\right)$ were completely inhibited at all tested concentrations of carbendazim. The best compatibility of tested Bio-control agents (BCAs) was observed with carboxin. The mycelial growth of $\mathrm{Tv}_{2}$ observed at 50 and 100ppm concentrations (carboxin) was statistically at par with untreated check, however, at $250 \mathrm{ppm}$ concentration significantly lower growth $(72.3 \mathrm{~mm})$ was recorded in $\mathrm{Tv}_{2}$ compared to untreated check $(90 \mathrm{~mm})$. The growth of antagonists were slightly inhibited by metalaxyl at its higher concentration, however, significantly lesser growth of antagonists was observed at all concentration of captan. These findings are in agreement with the finding of Mukhopadhay et-al (1992) who also reported the insensitivity of Trichoderma and Gliocladium spp. against the carboxin. The differentiating response of antagonistic flora to various fungicides might be due to their inherent resistance to the fungicides and their ability to degrade chemicals (Papavizas, 1985).

\subsection{Integration of Chemicals and Bio-agents against Wilt Complex Disease}

\subsubsection{Glasshouse Studies}

The Table 4 indicates that seed+seedling + spraying of carbendazim + metalaxyl and captan + metalaxyl were more effective than seed+seedling + soil treatment of $\mathrm{Gv}_{3}$ and $\mathrm{Tv}_{2}$ under glasshouse conditions. The treatment captan + metalaxyl recorded significantly higher wilt incidence (38.8\%) than observed in carbendazim + metalaxyl (31.9\%), however, when $T$. viride $\left(\mathrm{Tv}_{2}\right)$ and $T$. virens $\left(\mathrm{Gv}_{3}\right)$ were integrated with captan+metalaxyl it resulted in lesser wilt incidence which was at par with carbendazim + metalaxyl. The effectiveness of carboxin + metalaxyl was also observed when used in combination with fungal antagonists. The maximum disease reduction $(70.9 \%)$ ) over control was observed each in captan + metalaxyl $+T$. viride and captan + metalaxyl $+T$. virens. Carboxin + metalaxyl also recorded disease reduction of $47.3 \%$ over control. Under present investigation, $T$. viride $\left(\mathrm{Tv}_{2}\right)$ and $T$. virens $\left(\mathrm{Gv}_{3}\right)$ showed more resistance against the fungicides rather than $T$. harzianum $\left(\mathrm{Th}_{2}\right)$ which might be due to their inherent resistance to fungicides and their ability to degrade chemicals as described by Papavizas (1985). Similar to present findings the compatibility of Trichoderma spp. with metalaxyl has been reported earlier also (Annonymous, 2008). Khosla and Gupta (2008) observed the toxicity of carbendazim against the Trichoderma spp.

\subsubsection{Field Studies}

The data presented in Table 4 also revealed the similar trend in results as under pot culture studies. Superiority of carbendazim + metalaxyl, captan + metalaxyl $+\mathrm{Gv}_{3}$ and captan + metalaxyl $+\mathrm{Tv}_{2}$ was confirmed as higher disease reduction of 59.8, 58.6 and 58.0\% over control and maximum yield of 138.6, 137.0 and 135.6 q/ha was observed, 
respectively. The integration of BCAs with carboxin+metalaxyl resulted lesser wilt incidence compared to the individual treatment of BCAs and fungicides.

The present findings are supported by earlier works wherein integration of bio-control agents with fungicides gave significantly higher disease control in several crops than that obtained either by bio-control agent or by fungicide alone (Sawant \& Mukhopadyay 1990; Dubey, 1997). The seed and seedling treatment with captan, metalaxyl and carboxin may eradicate the wilt causing pathogens or other microflora thereby less competition for BCA to colonize the seed and root surface and proliferate (Chet et al. 1982; Ram et al. 2000). The subsequent application of compatible fungicides may support the growth of antagonists and may also prevent the plant form the attack of pathogens. The other workers also observed the additive effects of compatible fungicides and antagonists (Chattopadhyay \& Sen, 1996). Gour \& Sharma (2010) also integrated T. viride -1 or T. harzianum (TG-1) with metalaxyl and cymoxanil $8 \%$ + mancozeb $64 \%$ to control root rot in cotton. On the basis of present investigation it may be concluded that seed+seedlings + spraying of carbendazim + metalaxyl or captan + metalaxyl $+\mathrm{Gv}_{3}$ or captan + metalaxyl $+\mathrm{Tv}_{2}$ can be applied to manage the devastating wilt disease in Capsicum.

Table 1. In-vitro evaluation of fungicides against wilt complex pathogens

\begin{tabular}{|c|c|c|c|c|c|c|c|c|c|c|}
\hline \multirow{2}{*}{ Fungicide } & & \multirow{2}{*}{$\begin{array}{l}\text { Conc. } \\
(\mathrm{ppm})\end{array}$} & \multicolumn{4}{|c|}{ Radial growth (mm) } & \multicolumn{4}{|c|}{ Inhibition over check (\%) } \\
\hline & & & F.oxysporum & P.capsici & R.solani & S.rolfsii & F.oxysporum & P.capsici & R.solani & S.rolfsii \\
\hline \multirow{3}{*}{\multicolumn{2}{|c|}{$\begin{array}{l}\text { Copper } \\
\text { oxychloride }\end{array}$}} & 100 & 37.3 & 24.0 & 40.0 & 45.0 & 58.5 & 73.3 & 55.5 & 50.0 \\
\hline & & 250 & 28.0 & 18.6 & 33.6 & 36.6 & 68.8 & 79.3 & 62.6 & 59.3 \\
\hline & & 500 & 20.3 & 8.0 & 25.0 & 34.3 & 77.4 & 91.1 & 72.2 & 61.8 \\
\hline \multirow{3}{*}{\multicolumn{2}{|c|}{ Captan }} & 100 & 18.6 & 25.6 & 39.3 & 32.0 & 79.3 & 71.5 & 56.3 & 64.4 \\
\hline & & 250 & 10.0 & 15.3 & 31.6 & 22.6 & 88.8 & 83.0 & 64.8 & 74.8 \\
\hline & & 500 & 0.0 & 0.0 & 26.0 & 18.6 & 100.0 & 100.0 & 71.1 & 79.3 \\
\hline \multirow{3}{*}{\multicolumn{2}{|c|}{ Mancozeb }} & 100 & 30.0 & 25.0 & 26.3 & 45.6 & 66.6 & 72.2 & 70.7 & 49.3 \\
\hline & & 250 & 22.0 & 18.3 & 19.3 & 34.3 & 75.5 & 79.6 & 78.5 & 61.8 \\
\hline & & 500 & 16.0 & 8.0 & 15.0 & 28.3 & 82.2 & 91.1 & 83.3 & 68.5 \\
\hline Mancozeb & + & 100 & 18.6 & 31.6 & 24.0 & 40.3 & 79.3 & 64.8 & 73.3 & 55.2 \\
\hline Carbendazim & & 250 & 10.3 & 21.6 & 13.6 & 32.0 & 88.5 & 76.0 & 84.8 & 64.4 \\
\hline (Saaf) & & 500 & 6.0 & 18.0 & 0.0 & 28.0 & 93.3 & 80.0 & 100.0 & 68.8 \\
\hline Mancozeb & + & 100 & 24.3 & 18.0 & 20.6 & 39.0 & 73.0 & 80.0 & 77.1 & 56.6 \\
\hline \multirow{2}{*}{\multicolumn{2}{|c|}{$\begin{array}{l}\text { Metalaxyl } \\
\text { (Ridomil MZ.) }\end{array}$}} & 250 & 15.3 & 12.6 & 13.0 & 32.6 & 83.3 & 86.0 & 85.5 & 63.7 \\
\hline & & 500 & 10.6 & 0.0 & 8.3 & 27.0 & 88.2 & 100.0 & 90.7 & 70.0 \\
\hline \multirow{3}{*}{\multicolumn{2}{|c|}{$\begin{array}{l}\text { Thiophanate } \\
\text { methyl }\end{array}$}} & 50 & 23.0 & 76.3 & 19.3 & 67.0 & 74.4 & 15.2 & 78.5 & 25.5 \\
\hline & & 100 & 16.0 & 72.0 & 9.6 & 62.0 & 82.2 & 20.0 & 89.3 & 31.1 \\
\hline & & 250 & 10.3 & 70.6 & 0.0 & 58.6 & 88.5 & 21.5 & 100.0 & 34.8 \\
\hline \multirow{3}{*}{ Carboxin } & & 50 & 60.3 & 74.6 & 0.0 & 78.6 & 33.0 & 17.1 & 100.0 & 12.6 \\
\hline & & 100 & 55.6 & 71.6 & 0.0 & 72.0 & 38.2 & 20.4 & 100.0 & 20.0 \\
\hline & & 250 & 44.0 & 67.6 & 0.0 & 68.6 & 51.1 & 22.4 & 100.0 & 23.7 \\
\hline \multirow{3}{*}{\multicolumn{2}{|c|}{ Carbendazim }} & 50 & 0.0 & 86.6 & 24.3 & 68.3 & 100.0 & 3.7 & 73.0 & 24.1 \\
\hline & & 100 & 0.0 & 83.0 & 12.3 & 56.3 & 100.0 & 7.7 & 86.3 & 37.4 \\
\hline & & 250 & 0.0 & 80.3 & 0.0 & 53.0 & 100.0 & 10.7 & 100.0 & 41.1 \\
\hline \multirow{3}{*}{\multicolumn{2}{|c|}{ Metalaxyl }} & 50 & 85.6 & 0.0 & 65.0 & 70.0 & 4.8 & 100.0 & 27.7 & 22.2 \\
\hline & & 100 & 81.3 & 0.0 & 58.6 & 63.3 & 9.6 & 100.0 & 53.5 & 29.6 \\
\hline & & 250 & 76.0 & 0.0 & 53.0 & 58.0 & 15.5 & 100.0 & 41.1 & 35.5 \\
\hline Check & & - & 90.0 & 90.0 & 90.0 & 90.0 & - & - & - & - \\
\hline $\mathrm{CD}(\mathrm{P}=0.05)$ & & - & 3.18 & 3.46 & 3.75 & 3.84 & - & - & - & - \\
\hline
\end{tabular}


Table 2. Effect of fungicides on wilt incidence in bell pepper cv. California Wonder, under glass house conditions

\begin{tabular}{|c|c|c|c|c|c|c|}
\hline \multirow[t]{2}{*}{ Fungicides } & \multirow{2}{*}{$\begin{array}{l}\text { Concentration } \\
(\%)\end{array}$} & \multirow{2}{*}{$\begin{array}{l}\text { Seedling } \\
\text { emergence } \\
(\%)\end{array}$} & \multirow{2}{*}{$\begin{array}{l}\text { Increase } \\
\text { Check } \\
(\%)\end{array}$} & \multicolumn{2}{|c|}{$\begin{array}{l}\text { Wilt incidence }(\%) \\
\text { transplanting) }\end{array}$} & \multirow{2}{*}{$\begin{array}{c}\text { (Days after } \\
100\end{array}$} \\
\hline & & & & 40 & 80 & \\
\hline \multicolumn{7}{|c|}{ Seed Treatment (ST) + Seedling Dip (SD) } \\
\hline Captan & 0.3 & $\begin{array}{l}75.6 \\
(60.3)\end{array}$ & 40.5 & $\begin{array}{l}58.3 \\
(49.7)\end{array}$ & $\begin{array}{l}100.0 \\
(90.0)\end{array}$ & $\begin{array}{l}100.0 \\
(90.0)\end{array}$ \\
\hline Carbendazim & 0.2 & $\begin{array}{l}77.0 \\
(61.3)\end{array}$ & 43.1 & $\begin{array}{l}45.8 \\
(42.5)\end{array}$ & $\begin{array}{l}100.0 \\
(90.0)\end{array}$ & $\begin{array}{l}100.0 \\
(90.0)\end{array}$ \\
\hline Metalaxyl & 0.2 & $\begin{array}{l}73.3 \\
(58.8)\end{array}$ & 36.1 & $\begin{array}{l}70.8 \\
(57.2)\end{array}$ & $\begin{array}{l}100.0 \\
(90.0)\end{array}$ & $\begin{array}{l}100.0 \\
(90.0)\end{array}$ \\
\hline Carboxin & 0.2 & $\begin{array}{l}74.2 \\
(59.4)\end{array}$ & 37.9 & $\begin{array}{l}66.6 \\
(54.6)\end{array}$ & $\begin{array}{l}100.0 \\
(90.0)\end{array}$ & $\begin{array}{l}100.0 \\
(90.0)\end{array}$ \\
\hline Captan + Metalaxyl & 0.35 & $\begin{array}{l}78.0 \\
(62.0)\end{array}$ & 44.9 & $\begin{array}{l}54.1 \\
(47.3)\end{array}$ & $\begin{array}{l}100.0 \\
(90.0)\end{array}$ & $\begin{array}{l}100.0 \\
(90.0)\end{array}$ \\
\hline $\begin{array}{l}\text { Captan } \\
\text { Carbendazim }\end{array}$ & 0.35 & $\begin{array}{l}78.5 \\
(62.3)\end{array}$ & 45.9 & $\begin{array}{l}50.0 \\
(45.0)\end{array}$ & $\begin{array}{l}100.0 \\
(90.0)\end{array}$ & $\begin{array}{l}100.0 \\
(90.0)\end{array}$ \\
\hline $\begin{array}{l}\text { Carbendazim } \\
\text { Metalaxyl }\end{array}$ & 0.3 & $\begin{array}{l}79.5 \\
(63.0)\end{array}$ & 47.7 & $\begin{array}{l}41.6 \\
(40.1)\end{array}$ & $\begin{array}{l}100.0 \\
(90.0)\end{array}$ & $\begin{array}{l}100.0 \\
(90.0)\end{array}$ \\
\hline Carboxin + Metalaxyl & 0.3 & $\begin{array}{l}77.0 \\
(61.3)\end{array}$ & 43.1 & $\begin{array}{l}62.4 \\
(52.1)\end{array}$ & $\begin{array}{l}100.0 \\
(90.0)\end{array}$ & $\begin{array}{l}100.0 \\
(90.0)\end{array}$ \\
\hline \multicolumn{7}{|c|}{ Seed treatment (ST) + Seedling Dip (SD) + Spraying (15 days interval) } \\
\hline Captan + Metalaxyl & 0.2 & - & - & $\begin{array}{l}0.0 \\
(0.0)\end{array}$ & $\begin{array}{l}29.1 \\
(32.6)\end{array}$ & $\begin{array}{l}33.3 \\
(35.2)\end{array}$ \\
\hline $\begin{array}{l}\text { Captan } \\
\text { Carbendazim }\end{array}$ & 0.2 & - & - & $\begin{array}{l}4.1 \\
(11.6)\end{array}$ & $\begin{array}{l}29.1 \\
(32.6)\end{array}$ & $\begin{array}{l}45.8 \\
(42.2)\end{array}$ \\
\hline $\begin{array}{l}\text { Carbendazim } \\
\text { Metalaxyl }\end{array}$ & 0.15 & - & - & $\begin{array}{l}0.0 \\
(0.0)\end{array}$ & $\begin{array}{l}25.0 \\
(30.0)\end{array}$ & $\begin{array}{l}25.0 \\
(30.0)\end{array}$ \\
\hline Carboxin + Metalaxyl & 0.15 & - & - & $\begin{array}{l}20.8 \\
(27.1)\end{array}$ & $\begin{array}{l}50.0 \\
(45.0)\end{array}$ & $\begin{array}{l}58.3 \\
(49.7)\end{array}$ \\
\hline Check & - & $\begin{array}{l}53.8 \\
(47.1)\end{array}$ & - & $\begin{array}{l}100.0 \\
(90.0)\end{array}$ & $\begin{array}{l}100.0 \\
(90.0)\end{array}$ & $\begin{array}{l}100.0 \\
(90.0)\end{array}$ \\
\hline$C D(p=0.05)$ & - & 1.78 & - & 16.9 & 9.5 & 8.0 \\
\hline
\end{tabular}

Figures in parenthesis are transformed angular values

*The treatments excluding check, recorded 100 per cent wilt incidence, were not included in statistical analysis

Table 3. In-vitro evaluation of compatibility of different fungicides with the antagonists

\begin{tabular}{|c|c|c|c|c|c|c|c|}
\hline \multirow[b]{2}{*}{ Fungicides } & \multirow{2}{*}{$\begin{array}{l}\text { Concentration } \\
\text { (ppm) }\end{array}$} & \multicolumn{3}{|c|}{ Radial growth (mm) } & \multicolumn{3}{|c|}{ Inhibition over check (\%) } \\
\hline & & $\begin{array}{l}\text { T. harzianum } \\
\left(\mathrm{Th}_{2}\right)\end{array}$ & $\begin{array}{l}T . \text { viride } \\
\left(T v_{2}\right)\end{array}$ & $\begin{array}{l}\text { T. virens } \\
\left(G v_{3}\right)\end{array}$ & $\begin{array}{l}\text { T. harzianum } \\
\left(\mathrm{Th}_{2}\right)\end{array}$ & $\begin{array}{l}T . \text { viride } \\
\left(\mathrm{Tv}_{2}\right)\end{array}$ & $\begin{array}{l}T . \text { virens } \\
\left(G v_{3}\right)\end{array}$ \\
\hline \multirow{3}{*}{ Carbendazim } & 50 & 0.0 & 0.0 & 0.0 & 100.0 & 100.0 & 100.0 \\
\hline & 100 & 0.0 & 0.0 & 0.0 & 100.0 & 100.0 & 100.0 \\
\hline & 250 & 0.0 & 0.0 & 0.0 & 100.0 & 100.0 & 100.0 \\
\hline \multirow{3}{*}{ Carboxin } & 50 & 90.0 & 90.0 & 90.0 & 0.0 & 0.0 & 0.0 \\
\hline & 100 & 85.3 & 84.6 & 90.0 & 5.2 & 6.0 & 0.0 \\
\hline & 250 & 74.6 & 72.3 & 85.0 & 17.1 & 19.6 & 5.5 \\
\hline \multirow{3}{*}{ Captan } & 100 & 75.6 & 75.6 & 80.3 & 16.0 & 16.0 & 10.7 \\
\hline & 250 & 67.3 & 67.3 & 71.0 & 25.2 & 25.2 & 21.1 \\
\hline & 500 & 54.0 & 54.0 & 61.6 & 40.0 & 40.0 & 31.5 \\
\hline \multirow{3}{*}{ Metalaxyl } & 50 & 85.3 & 84.6 & 88.3 & 5.2 & 6.0 & 1.8 \\
\hline & 100 & 74.6 & 73.3 & 80.0 & 17.1 & 18.5 & 11.1 \\
\hline & 250 & 67.3 & 70.0 & 75.3 & 25.2 & 22.2 & 16.3 \\
\hline Check & - & 90.0 & 90.0 & 90.0 & - & - & - \\
\hline$C D(p=0.05)$ & - & 7.4 & 6.4 & 6.5 & - & - & - \\
\hline
\end{tabular}


Table 4. Effect of fungicides and antagonists alone and in combinations on wilt complex disease of bell-pepper cv. California Wonder

\begin{tabular}{|c|c|c|c|c|c|c|c|}
\hline \multirow{2}{*}{\multicolumn{3}{|c|}{$\begin{array}{l}* * \text { Treatment } \\
(\mathrm{ST}+\mathrm{SD}+\text { Spraying })\end{array}$}} & \multicolumn{2}{|c|}{ Glass house conditions } & \multicolumn{3}{|l|}{ Field condition } \\
\hline & & & \multirow{2}{*}{$\begin{array}{l}\text { Wilt } \\
\text { incidence (\%) } \\
38.8 \\
(38.0)\end{array}$} & \multirow{2}{*}{$\begin{array}{l}\begin{array}{l}\text { Disease } \\
\text { over control (\%) }\end{array} \\
61.2\end{array}$} & \multirow{2}{*}{$\begin{array}{l}\text { Wilt } \\
\text { incidence (\%) } \\
30.1 \\
(33.2)\end{array}$} & \multirow{2}{*}{$\begin{array}{l}\text { Disease } \begin{array}{c}\text { reduction } \\
\text { over control (\%) }\end{array} \\
53.6\end{array}$} & \multirow{2}{*}{$\begin{array}{l}\begin{array}{l}\text { Yield } \\
\text { q/ha }\end{array} \\
130.4\end{array}$} \\
\hline $\mathrm{T}_{1}$ & $\begin{array}{l}\text { Captan } \\
\text { Metalaxyl }\end{array}$ & + & & & & & \\
\hline $\mathrm{T}_{2}$ & $\begin{array}{l}\text { Carbendazim } \\
\text { Metalaxyl }\end{array}$ & + & $\begin{array}{l}31.9 \\
(34.3)\end{array}$ & 68.1 & $\begin{array}{l}26.1 \\
(30.7)\end{array}$ & 59.8 & 138.6 \\
\hline $\mathrm{T}_{3}$ & $\begin{array}{l}\text { Carboxin } \\
\text { Metalaxyl }\end{array}$ & + & $\begin{array}{l}59.7 \\
(50.5)\end{array}$ & 40.3 & $\begin{array}{l}34.0 \\
(35.6)\end{array}$ & 47.6 & 122.6 \\
\hline $\mathrm{T}_{4}$ & $\begin{array}{c}T . \\
\left(\mathrm{Th}_{2}\right)\end{array}$ & & $\begin{array}{l}52.7 \\
(46.5)\end{array}$ & 47.3 & $\begin{array}{l}51.9 \\
(46.0)\end{array}$ & 20.1 & 82.1 \\
\hline $\mathrm{T}_{5}$ & T. virens $\left(\mathrm{Gv}_{3}\right)$ & & $\begin{array}{l}43.0 \\
(40.9)\end{array}$ & 57.0 & $\begin{array}{l}50.0 \\
(45.0)\end{array}$ & 22.0 & 84.3 \\
\hline $\mathrm{T}_{6}$ & $\mathrm{~T}_{1}^{*}+\mathrm{T}_{4}$ & & $\begin{array}{l}29.1 \\
(32.6)\end{array}$ & 70.9 & $\begin{array}{l}27.3 \\
(32.2)\end{array}$ & 58.0 & 135.6 \\
\hline $\mathrm{T}_{7}$ & $\mathrm{~T}_{1}^{*}+\mathrm{T}_{5}$ & & $\begin{array}{l}29.1 \\
(32.6)\end{array}$ & 70.9 & $\begin{array}{l}26.9 \\
(31.2)\end{array}$ & 58.6 & 137.0 \\
\hline $\mathrm{T}_{8}$ & $\mathrm{~T}_{3}^{*}+\mathrm{T}_{4}$ & & $\begin{array}{l}45.8 \\
(42.5)\end{array}$ & 54.2 & $\begin{array}{l}30.8 \\
(33.7)\end{array}$ & 52.6 & 129.5 \\
\hline $\mathrm{T}_{9}$ & $\mathrm{~T}_{3}^{*}+\mathrm{T}_{5}$ & & $\begin{array}{l}38.8 \\
(38.0)\end{array}$ & 61.2 & $\begin{array}{l}30.6 \\
(33.5)\end{array}$ & 52.9 & 130.5 \\
\hline $\mathrm{T}_{10}$ & Control & & $\begin{array}{l}100.0 \\
(90.0)\end{array}$ & - & $\begin{array}{l}65.0 \\
(53.7)\end{array}$ & - & 63.1 \\
\hline & $\mathrm{CD}(\mathbf{p}=\mathbf{0 . 0 5})$ & & 5.0 & - & 2.0 & - & 3.0 \\
\hline
\end{tabular}

Figures in parenthesis are transformed angular value

$\mathrm{T}_{1}=\mathrm{ST}+\mathrm{SD} @ 0.35 \%$, Spraying@0.25\%; T2, T, ST + SD@0.25\%, Spraying@0.2\%;

$\mathrm{T}_{4}, \mathrm{~T}_{5}, \mathrm{ST}+\mathrm{SD}$ with antagonist suspension $\left(10^{7}\right.$ spores $\left./ \mathrm{ml}\right)$; Soil treatment @ $20 \mathrm{~g} /$ plot soil.

*Half dose of fungicides applied as ST $+\mathrm{SD}$

ST - Seed Treatment; SD - Seedling Dip

**The sprays were conducted at 15days interval starting from the first appearance of disease

\section{References}

Annonymous. (2008). HC Tech Bulletin. BioWorks, Rawson Rd., Suite 205 Victor, New York. pp. 1-2.

Anonymous. (1989). Annual Progress Report, Division of Plant Pathology, Sher-e-Kashmir University of Agricultural Sciences and Technology, Kashmir, Shalimar, Srinagar, p. 30.

Babadoost, M., \& Islam, S. Z. (2003). Fungicide seed treatment effects on seedling damping- Off of pumpkin caused by Phytophthora capsici. Plant Disease, 87(1), 65-68.

Chattopadhyay, C., \& Sen, B. (1996). Integrated management of Fusarium wilt of Muskmelon caused by Fusarium oxysporum. Indian Journal of Mycology and Plant Pathology, 26(2), 162-170.

Chet, I.Elad, Y., Koflan, A., Hadar, Y., \& Katan, J. (1982). Integrated control of soil borne and bulb borne pathogen in Iris. Phytoparasitica, 10, 229-231.

Chowdary, K. A., Reddy, D.R., \& Rao, K. C. (1998). Efficacy of systemic (Triazoles) and non-systemic fungicides against sclerotial wilt of bell pepper caused by Sclerotium rolfsii Sacc. Indian J Plant Prot., 26(2), 125-130.

Dubey, S. C. (1997). Biological control of web blight of groundnut caused by Thanatephorus cucumeris. Golden Jubilee international Conference of IPS at IARI, New Delhi 10-15 Nov. 1997. p.194.

Dubey, S. C., \& Patel, B. (2001). Determination of tolerance in Thanatephorus cucumeris, Trichoderma viride, Gliocladium virens and Rhizobium sp. to fungicides. Indian Phytopathology, 54(1), 98-101.

Gaur, R. B., \& Sharma R. N. (2010). Biocontrol of Root Rot in Cotton and Compatibility of Potential Bioagents with fungicides. Indian Journal of Plant Protection, 38(2), 176-182. 
Kaur, S. (1993). Fusarium wilt - a cause of chilli crop failure in Punjab. Plant Disease Research, 8, 181-183.

Khosla K., \& Gupta A. K. (2008). Integration of fungicides and Trichoderma viride for management of seedling blight disease of apple caused by Sclerotium rolfsii. Indian Phytopathology, 61, 43-48.

Makhopadhay, A. N., Shreshtha, S. M., \& Mukherjee, P. K. (1992). Biological seed treatment for control of soil-born plant pathogens. FAO Plant Protection Bulletin, 40, 21-30.

Najar, A. G. (2001). Cause and management of chilli wilt in Kashmir. Ph.D thesis submitted to Sher-e-Kashmir University of Agricultural Science and Technology (Kashmir) Shalimar Campus, Srinagar Jammu and Kashmir India. p. 143.

Papavizas, G. C. (1985). Trichoderma and Glicladium: Biology, ecology and potential for biocontrol. Annual Review of Phytopathology, 23, 23-54.

Ram, D., Mathur, K., Lodha B. C., \& Webster, J. (2000). Evaluation of resident biocontrol agents as seed treatments against ginger rhizome rot. Indian Phytopathology, 53(4), 450-454.

Sawant, I. S., \& Mudhopadhay, A.N. (1990). Integration of metaxyl with Trichoderma harzianum for the control of Pythium damping-off in sugar beet. Indian Phytopathology, 43, 535-541.

Schemitz, H. (1930). Poisoned food technique Indust. Engin. Chem Analyst, p. 361.

Shali, S. (2000). Studies on chilli wilt in Jammu M.Sc Thesis submitted to Sher-e-Kashmir University of Agriculture Science and Technology Jammu, p. 45.

Sharma, R. L., Singh, B. P., Thakur, M. P., \& Verma, K. P. (2002). Chemical management of linseed wilt caused by Fusarium oxysporum f. sp lini. Annals of Plant Protection Science, 10(2), 365-410.

Simon, J. N., Simon, J. E. Simons, J. L., \& Wingberg, T. (1990). Control of Phytophtora crown rot in bell pepper with direct sprays of metalaxyl. Proceedings of the Florida state Horticultural Society, 103, 120-121. 